University of Nebraska - Lincoln

DigitalCommons@University of Nebraska - Lincoln

2010

Study of strawberry flavored milk under pulsed electric field processing

\author{
Daniela Bermúdez-Aguirre \\ Washington State University \\ Jaime A. Yáñez \\ Washington State University \\ C. Patrick Dunne \\ US Army Natick Soldier RDEC \\ Neal M. Davies \\ Washington State University \\ Gustavo V. Barbosa-Cánovas \\ Washington State University, barbosa@wsu.edu
}

Follow this and additional works at: https://digitalcommons.unl.edu/usarmyresearch

Part of the Operations Research, Systems Engineering and Industrial Engineering Commons

\footnotetext{
Bermúdez-Aguirre, Daniela; Yáñez, Jaime A.; Dunne, C. Patrick; Davies, Neal M.; and Barbosa-Cánovas, Gustavo V., "Study of strawberry flavored milk under pulsed electric field processing" (2010). US Army Research. 111.

https://digitalcommons.unl.edu/usarmyresearch/111

This Article is brought to you for free and open access by the U.S. Department of Defense at DigitalCommons@University of Nebraska - Lincoln. It has been accepted for inclusion in US Army Research by an authorized administrator of DigitalCommons@University of Nebraska - Lincoln.
} 


\title{
Study of strawberry flavored milk under pulsed electric field processing
}

\author{
Daniela Bermúdez-Aguirre ${ }^{\mathrm{a}}$, Jaime A. Yáñez ${ }^{\mathrm{b}}, \mathrm{C}$. Patrick Dunne ${ }^{\mathrm{c}}$, \\ Neal M. Davies ${ }^{\mathrm{b}}$, Gustavo V. Barbosa-Cánovas ${ }^{\mathrm{a}, *}$ \\ a Biological Systems Engineering Department, Washington State University, Pullman, WA 99164-6120, USA \\ b Department of Pharmaceutical Sciences, Washington State University, Pullman, WA 99164-6534, USA \\ c US Army Natick Soldier RDEC Natick, MA, 01760-5018, USA
}

\section{A R T I C L E I N F O}

\section{Article history:}

Received 27 April 2010

Accepted 21 July 2010

\section{Keywords:}

Allura Red

HPLC

Strawberry milk

Pulsed electric fields

\begin{abstract}
A B S T R A C T
Few studies exist on flavored milk processed by pulsed electric fields (PEF). The main concern is product stability. This study aimed to analyze the degradation of coloring agent Allura Red in strawberry milk under PEF. Four systems were tested containing Allura Red: two commercial milks and two model systems. PEF conditions were $40 \mathrm{kV} / \mathrm{cm}, 48$ pulses $(2.5 \mu \mathrm{s})$, and $55^{\circ} \mathrm{C}$; coloring agent was quantified via RP-HPLC. After processing, only minor changes were observed in color, Allura Red concentration, and $\mathrm{pH}$. During storage (32 d) at refrigerated conditions $\left(4^{\circ} \mathrm{C}\right.$ ) commercial samples maintained $\mathrm{pH}$ above 6 . Model systems dropped below pH 6 after 10 days of storage. Color of samples showed important decrease in $a^{*}$; hue angle and chroma changed during storage. HPLC analysis reported a bi-phasic effect in Allura Red concentrations versus time. Concentration changed, reaching a maximum value during the middle of storage, possibly attributed to microbial growth, $\mathrm{pH}$ reduction, or interaction of proteins. However, PEF affected the stability of Allura Red in milk when additional ingredients were not added to the product.
\end{abstract}

(c) 2010 Elsevier Ltd. All rights reserved.

\section{Introduction}

There are a number of commercially flavored milks such as chocolate, vanilla, banana, orange and strawberry. Chocolate milk is the most popular flavored milk, especially with children (90\% like its taste); it has a high protein content and is a good source of vitamins, calcium and other nutrients. Strawberry flavored milk also demonstrates high acceptability with the consumer (Miller, Jarvis, \& McBean, 2007). Milk is not only important in maintaining good health, keeping bones strong, and providing nutrients during the development of children, it also one of the main sources of protein in certain populations. For example, in combat rations for soldiers, milk is an important component of the different menus. Combat rations also must be part of a quality lifestyle provided to soldiers, while at the same time, rations should cover all of their nutritional needs. At the department of US Army Natick Soldier Center, food researchers are constantly looking for better products to provide more foods and improved choices on the soldiers' menus. Some of the current milkbased beverages for military rations are dairy shakes (chocolate, vanilla, strawberry and banana) (NSRDEC, 2007). However, the shelflife of fluid milk products, supplied as an enhancement to group rations, is sometimes limited because of the processing conditions,

\footnotetext{
* Corresponding author. Department of Biological Systems Engineering, Washington State University, Pullman, WA 99164-6120, USA. Tel.: +1 509335 6188; fax: +1 509 3352722.

E-mail address: barbosa@wsu.edu (G.V. Barbosa-Cánovas).
}

shipping and extreme conditions experienced during storage in rugged environments. For feeding purposes, storage life of the product must be as long as possible under the most diverse conditions, but at the same time, it should have good sensory characteristics such as flavor, taste, color and appearance. Conventional food processing operations (e.g. drying, pasteurization, blanching, canning, etc.) have the disadvantage of decreasing a food's overall quality, destroying some vitamins and pigments, and denaturalization of some proteins or volatizing odors, all of which can affect the final product. Nevertheless, these unit operations must be conducted to inactivate the pathogenic microorganisms in food, to reduce the load of spoilage microorganisms and enzymatic activity, and to extend the shelf-life of the product. Currently, a group of novel emerging technologies such as high hydrostatic pressure, pulsed electric fields, ultrasound, and ultraviolet are being tested on foods to ensure the microbiologically safety and fresh-like characteristics of products. Pulsed electric fields (PEF) technology has shown positive effects on inactivating pathogenic bacteria and reducing the number of spoilage microorganisms in milk (Sobrino-López, \& Martín-Belloso, 2008; Bendicho, BarbosaCánovas, \& Martín-Belloso, 2002; Odriozola-Serrano, Bendicho-Porta, \& Martín-Belloso, 2006; Craven et al., 2008) Also, it may be feasible to extend the shelf-life of milk with PEF, retarding the growth of mesophilic bacteria up to 80 days with only minor effects on quality (Sepúlveda, Góngora-Nieto, Guerrero, \& Barbosa-Cánovas, 2005).

Color of food is an important quality parameter that may determine acceptability or rejection by the consumer (Abdullah, Badaruddin, Sayeed, Ali, \& Riaz, 2008). Color is important in flavor and 
taste recognition and identification, as well as in food preference (Gifford, \& Clydesdale, 1986). Children often prefer beverages and other products with attractive colors rather as opposed to colorless foods. Color of food has a psychological effect on how the product is perceived by the consumer. For example, the degree of sweetness in cherry-flavored drinks was perceived by consumers different because of the presence of red-colored pigments (Gifford, \& Clydesdale, 1986). Allura Red AC or FD\&C Red No. 40 is a red powder that is soluble in water; it is used as an additive in colored beverages, candy, cereals, confections, gelatins, puddings, ice cream, condiments, dairy products, and more. School children are the main consumers of these products, such as non-alcoholic flavored drinks, confectionery, and desserts including flavored milk products (Tennant, 2008). Allura Red is an organic molecule that can be classified as a monoazo structure $(\mathrm{N}=\mathrm{N})$; it has been listed for use as in foods since 1971 (Thorngate, 2002). Regulations of this color by the FDA are in accordance with Good Manufacturing Practice and must be certified as a food additive before being used in food products (CFR, 2001). Overdose of this additive has shown some reproductive effects when tested at experimental levels. The $\mathrm{TDL}_{0}$ (Toxic Dose Low) is the lowest dose over a given period of time capable of producing any toxic effect or carcinogenic, neoplastigenic or teratogenic effects in both animals and humans; for Red No. 40 the $\mathrm{TDL}_{0}$ is $38,500 \mathrm{mg} / \mathrm{kg}$, as tested in rats via oral ingestion (Lewis, 1989). Hyperactivity has been reported in children as a result of ingestion of this colorant in high concentration (Anonymous, 1984); nevertheless, the reported average daily intake in human beings is $100 \mathrm{mg} / \mathrm{kg}$ (Thorngate, 2002), which also represents the maximum amount allowed for this colorant in nonalcoholic beverages $(100 \mu \mathrm{g} / \mathrm{ml})$ in Europe (Al-Degs, 2009). In a detailed study conducted by the Union of European Beverages Association, it was shown that the highest usage of Allura Red in beverages was $21 \mathrm{mg} / \mathrm{l}$ (Tennant, 2008).

Some of the analytical techniques used for determination of synthetic colorants in food are thin-layer chromatography, derivative spectrometry, adsorptive voltammetry (Alghamdi, 2005), capillary electrophoresis, reverse-phase liquid chromatography (RPLC) and ion-pair RPLC (Chen, Mou, Hou, Riviello, \& Ni, 1998), visible spectrophotometry, and high performance liquid chromatography (Al-Degs, 2009).

The objective of this research was to study the effect of pulsed electric fields in processing strawberry flavored milk, using two commercial brands and two model systems, and to evaluate the physicochemical changes and possible degradation of Allura Red after PEF processing and during refrigerated storage (32 d).

\section{Materials and methods}

\subsection{Milk samples and model systems}

Two commercial brands of strawberry flavored milk $\left(A_{1}\right.$ and $\left.A_{2}\right)$ were purchased at the local supermarket. Initial characterization of the milks consisted of microbial evaluation (mesophilic load) and assessment of color, $\mathrm{pH}$ and concentration of Allura Red. Milk samples were kept at $4{ }^{\circ} \mathrm{C}$ until processed but no longer than $48 \mathrm{~h}$. Two model systems for strawberry milk ( $B_{1}$ and $B_{2}$ ) were prepared using reduced fat unflavored pasteurized milk (2\%) (purchased at a local supermarket); then sucrose and Allura Red AC (Sigma-Aldrich ${ }^{\circledR} 458848$ ) were added as a coloring agent ( $80 \%$ dye content). Model system $1\left(B_{1}\right)$ consisted of milk, sucrose (5.5\%), and Allura Red AC (0.01\%), using the minimum amount of coloring agent recommended for flavored milk according to the patent (WO/2004/100671). Model system $2\left(B_{2}\right)$ consisted of milk, sucrose (5.5\%) and Allura Red AC (0.2\%) using the maximum allowable concentration for flavored milk according to the above mentioned patent. Even though these concentrations are higher than those used in commercial samples, they were tested to study behavior under PEF in a wide range of concentrations. The composition of $A_{1}$ according to the manufacturing label was as follows: reduced fat milk with vitamin A Palmitate and vitamin D3 added, high fructose corn syrup, sugar, nonfat milk, calcium, carbonate, potassium citrate, artificial flavors, carrageenan, citric acid, salt, Red 40 (Allura Red), and Blue 1. The composition of $A_{2}$ was milk, high fructose corn syrup, nonfat milk, natural and artificial flavors, carrageenan, Red 40 (Allura Red), and vitamin D3. The code for each control sample respectively was the following: $A_{1 C}, A_{2 C}, B_{1 C}$ and $B_{2 C}$; and for PEF processed samples, $A_{1 P}, A_{2 P}, B_{1 P}$, and $B_{2 P}$. Again, samples were characterized according to microbial load, color, $\mathrm{pH}$ and concentration of Allura Red. Samples were kept at $4{ }^{\circ} \mathrm{C}$ until used.

\subsection{Pulsed electric fields treatment}

A pilot plant pulsed electric fields (PEF) system manufactured by Physics International (San Leandro, CA) consisting of a cylindrical concentric-electrodes treatment chamber was used to apply the desired treatments to the milk (Qin et al., 1995). The continuous treatment chamber had a volume of $25 \mathrm{~cm}^{3}$ with a gap between the stainless steel electrodes of $0.6 \mathrm{~cm}$.

Frequency was kept constant at $10 \mathrm{~Hz}$ and flow was set up at $490 \mathrm{ml} / \mathrm{min}$. Flow rate of the flavored milk was set up and controlled with a rotary pump (Masterflex 7654-00, Cole Parmer Instruments Co., Chicago, IL). Treatments at peak electric fields of $40 \mathrm{kV} / \mathrm{cm}$ were used in combination with 48 pulses ( $2.5 \mu$ s pulse-width each). A refrigerated bath and recirculation system was used to keep the milk temperature at or below $55^{\circ} \mathrm{C}$. Inlet and outlet temperatures of the treatment chamber were monitored with digital in-line thermocouples (Cole-Palmer, Vernon Hills, IL) and registered. The difference between the inlet and outlet temperature of milk during processing was around $45^{\circ} \mathrm{C}$ for all samples. Energy consumption, electric field intensity, pulse width, and pulse shape were directly measured with a digital oscilloscope (Hewlett-Packard 54530A, Colorado Springs, CO) connected to the treatment chamber through high voltage probes. These processing conditions were chosen because previous research of unflavored milk showed their effectiveness in inactivating pathogenic bacteria, reducing spoilage loads, and providing longer shelf-life.

\subsection{Microbiological analysis}

The initial load of microorganisms was evaluated in the flavored and unflavored milks. Plate Count Agar (Difco Becton, Dickinson and Co., Sparks, MD) was used for mesophiles aerobes. Serial dilutions were made with peptone water before pouring samples into dishes. These were incubated at $35{ }^{\circ} \mathrm{C}$ for $48 \mathrm{~h}$. For the PEF treatments, the microbial counts were evaluated after 48 pulses. Samples were analyzed in duplicate.

\subsection{1. $\mathrm{pH}$}

$\mathrm{pH}$ was determined by direct immersion in the samples with a potentiometer (Orion Research Inc., Boston, MA). The potentiometer was calibrated previously with two standards ( $\mathrm{pH} 4$ and 7). Each sample was measured in triplicate.

\subsubsection{Color}

Hunter color parameters $\left(L^{*}, a^{*}, b^{*}\right)$ were measured in samples after processing and during storage. Lightness to darkness $\left(L^{*}\right)$ (100 to $0)$, redness $(+)$ to greenness $(-)\left(a^{*}\right)$, and yellowness $(+)$ to blueness $(-)\left(b^{*}\right)$ color parameters were determined using a Minolta CM-2002 spectrophotometer (Minolta Camera Co., Osaka, Japan) in the reflection mode. Twenty $\mathrm{ml}$ of each milk sample were poured into sterile plastic bags. A white ceramic plate was used for standardizing the instrument $\left(L^{*}=93.4, a^{*}=-0.67, b^{*}=0.78\right)$. Each sample was read in triplicate. 
The net color difference was evaluated with the following equation, using the parameters $L^{*}, a^{*}$ and $b^{*}$ and comparing the different treatments with the untreated milk for each system from the beginning to end of storage life.

$\Delta E^{*}=\sqrt{\left(\Delta L^{*}\right)^{2}+\left(\Delta a^{*}\right)^{2}+\left(\Delta b^{*}\right)^{2}}$

Hue angle $\left(h^{*}\right)$ was determined using the following relationship:

$h^{*}=\tan ^{-1}\left(\frac{b^{*}}{a^{*}}\right)$

The chroma or saturation index $\left(C^{*}\right)$ was evaluated as follows:

$C^{*}=\left(a^{* 2}+b^{* 2}\right)^{1 / 2}$

\subsection{High Performance Liquid Chromatography (HPLC) analysis}

\subsubsection{Materials}

Allura Red and sodium acetate were purchased from Sigma (St. Louis, MO, USA). HPLC grade acetonitrile and water were purchased from J. T. Baker (Phillipsburg, NJ, USA). Commercial samples $\left(A_{1}, A_{2}\right)$ and model systems $\left(B_{1}, B_{2}\right)$ were used before and after PEF treatments to quantify the concentration of Allura Red.

\subsubsection{Allura Red extraction}

Stock solutions of Allura Red and kaempferol (internal standard, IS) were prepared in HPLC methanol, around $100 \mu \mathrm{g} / \mathrm{ml}$, and stored at $-20{ }^{\circ} \mathrm{C}$ protected from the light. A $5 \mathrm{ml}$ aliquot of each sample was collected and mixed with ice-cold HPLC acetonitrile, vortexed for $30 \mathrm{~s}$, and centrifuged at 3500 RPM for 8 min (Lonnerdal, Woodhouse, \& Glazier, 1987). The supernatant was transferred to new tubes and any precipitate was discarded. Next, $100 \mu \mathrm{l}$ of kaempferol was added to each sample, vortexed, and dried to completion under a constant stream of compressed nitrogen gas. Each sample was reconstituted in $500 \mu \mathrm{l}$ of HPLC acetonitrile, vortexed, and centrifuged, followed by $100 \mu \mathrm{l}$ injected into the HPLC.

\subsubsection{Chromatographic conditions}

For quantification of Allura Red, the HPLC system utilized was a Shimadzu HPLC (Kyoto, Japan) consisting of two LC-10ATVP pumps, SIL-10AF auto injector, SPD-M10A VP spectrophotometric diode array detector, and SCL-10A VP system controller. Data collection and integration were accomplished using Shimadzu EZ Start 7.1.1 SP1 software (Kyoto, Japan). The method was adapted from a report by Kirschbaum, Krause, Pfalzgraf, and Brückner (2003)); the analytical column was a Phenomenex Luna (2) $\mathrm{C}_{18}$ column $(250 \times 4.60 \mathrm{~mm}$, i.d. $5 \mu \mathrm{m}$ particle size, Torrance CA, USA). The mobile phase consisted of $100 \mathrm{mM}$ sodium acetate (NaOAc) (mobile phase A) and $100 \%$ acetonitrile ( $\mathrm{MeCN}$ ) (mobile phase B). Separation was carried out at ambient temperature $\left(25 \pm 1{ }^{\circ} \mathrm{C}\right)$, and UV detection at $520 \mathrm{~nm}$ for Allura Red and $370 \mathrm{~nm}$ for kaempferol (internal standard). Standard curves were prepared in reduced fat milk with known concentrations of Allura Red.

\subsubsection{Storage life}

PEF treated milk samples were collected in sterile plastic bags and stored at $4{ }^{\circ} \mathrm{C}$ for 40 days for shelf-life studies. Each bag sample was used and discarded after analysis. Every other day, the physicochemical characteristics ( $\mathrm{pH}$ and color) were evaluated. The microbial loads were poured into Plate Count Agar to count the mesophiles aerobes. Samples were taken from a different bag each day, diluted with peptone water and poured into dishes. Samples were incubated at $35^{\circ} \mathrm{C}$ for $48 \mathrm{~h}$. Every fifth day the coloring agent concentration was quantified using HPLC following the methodology described previously.

\subsection{Results and discussion}

2.5.1. $\mathrm{pH}$

In Fig. 1, the pH behavior of samples is shown for all the PEF treated samples. For commercial and untreated samples $\left(A_{1 C}\right.$ and $\left.A_{2} c\right), p H$ remained almost constant for one month of storage without important changes. However, PEF treated commercial samples $\left(A_{1 P}\right.$ and $\mathrm{A}_{2 \mathrm{P}}$ ) showed a decrease in $\mathrm{pH}$ after the first week of storage, changing from 6.7 to 6.3 and remaining at this value for most of the storage period; a final drop in value occurred after day 30 possibly because of the production of lactic acid bacteria. In all cases (treated and untreated), the $\mathrm{pH}$ was still within the range of commercial milk after 25 days of storage.

Both model systems showed interesting $\mathrm{pH}$ behavior during storage; $\mathrm{pH}$ of samples not processed with $\mathrm{PEF}\left(\mathrm{B}_{1 \mathrm{C}}\right.$ and $\left.\mathrm{B}_{2 \mathrm{C}}\right)$ dropped quickly after 7 days of storage and behavior was very similar between them. Samples treated with PEF $\left(B_{1 P}\right.$ and $\left.B_{2 P}\right)$ showed a slower decrease of $\mathrm{pH}$ compared to untreated samples, however, at the end of storage $\mathrm{pH}$ was below 5 . The reason for this drop could be the growth of lactobacillus and production of lactic acid in the milk, in addition to other possible chemical reactions taking place. In commercial brands there are other ingredients in addition to ones tested in this study that could be providing stability to the system and maintaining $\mathrm{pH}$ values during storage.

\subsubsection{Color}

Immediately after processing, samples did not show any important changes in color, or at least showed similar appearance to those prior to processing. Analytical measurements confirmed that the same Hunter color parameters $L^{*}, a^{*}$ and $b^{*}$ existed between the control samples and respective PEF treated samples after processing. However, during storage at $4{ }^{\circ} \mathrm{C}$ some samples showed important variations. The three Hunter color parameters were quantified,
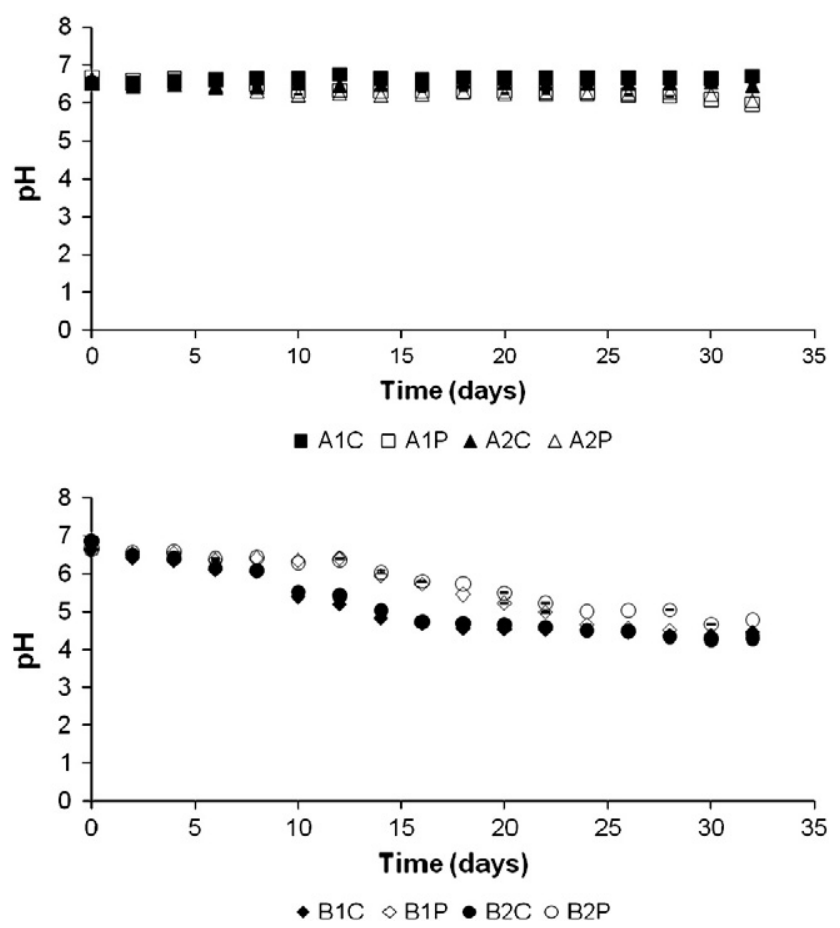

Fig. 1. $\mathrm{pH}$ behavior during storage $\left(4^{\circ} \mathrm{C}\right)$ of strawberry flavored milk; commercial brands (control: $A_{1 C}$ and $A_{2 C}$; processed $A_{1 P}$ and $A_{2 P}$ ) and model systems (control: $B_{1 C}$ and $\mathrm{B}_{2 \mathrm{C}}$; processed $\mathrm{B}_{1 \mathrm{P}}$ and $\mathrm{B}_{2 \mathrm{P}}$ ). 
however $a$, which is of interest because of its meaning, showed changes in the red and green regions. A more positive value means the product is closer to the red region while a negative number means it is closer to the green region. The commercial samples (Fig. 2) retained a constant color according to the $a^{*}$ value and were pasteurized by Ultra High Temperature (UHT). Abdullah et al. (2008) showed that there was a strong affinity for Allura Red and milk proteins such as caseins; even during heating, color of the dye remained constant because of strong binding with proteins. However, these same samples when treated with PEF lost color after 20 days of storage, with a marked decrease in $a$, dropping below zero. One of the physicochemical mechanisms from which color is produced involves electron transitions between molecular orbitals. Changes in bond conjugation in an organic molecule such as delocalization of electrons or presence of electron donor and acceptor groups affect the absorption of light, causing changes in color (Thorngate, 2002). Here, it is important to mention that the use of pulsed electricity has an observable effect on the stability of the coloring agent Allura Red in flavored milk. Both commercial samples, regardless of the rest of the ingredients, showed this decrease and remained constant until the end of storage (day 32), which could be due the effect of PEF on the proteins of milk. After the formation and binding of dye-protein, the intensity of the electric field could disrupt the stability of this bond, breaking it, with the possible loss of color that was observable in the low concentration of Allura Red in the commercial samples.

Model systems also showed an interesting behavior of $a^{*}$ parameter; the model with the lowest allowed concentration of Allura Red $\left(B_{1}\right)$ was discolored after 10 days of storage regardless of whether it was pulsed or not. PEF only retarded the loss of color for two days followed by discoloration later. Model system $B_{2}$ (with the highest coloring agent concentration) maintained constant color during storage regardless of whether the sample was pulsed or not. This suggests that because the coloring agent is more concentrated,

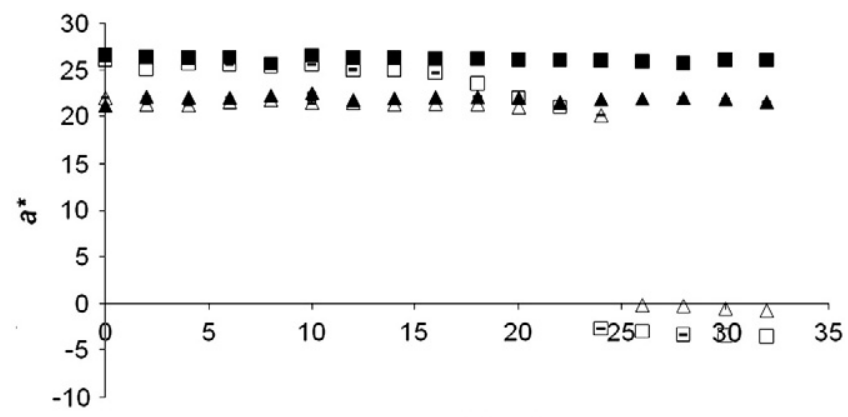

Time (days)

- A1C $\square \mathrm{A} 1 \mathrm{P} \triangle \mathrm{A} 2 \mathrm{C} \triangle \mathrm{A} 2 \mathrm{P}$

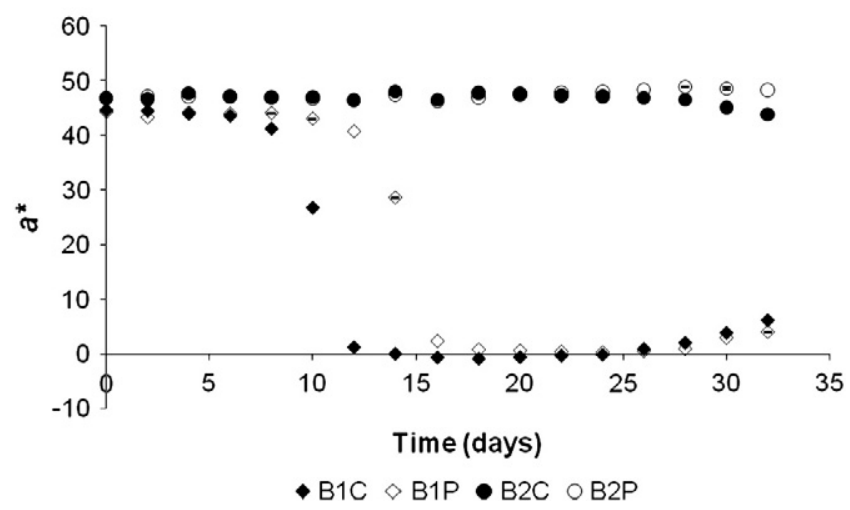

Fig. 2. $a^{*}$ color parameter behavior during storage $\left(4{ }^{\circ} \mathrm{C}\right)$ of strawberry flavored milk; commercial brands (control: $A_{1 C}$ and $A_{2 C}$; processed $A_{1 P}$ and $A_{2 P}$ ) and model systems (control: $\mathrm{B}_{1 \mathrm{C}}$ and $\mathrm{B}_{2} \mathrm{C}$; processed $\mathrm{B}_{1 \mathrm{P}}$ and $\mathrm{B}_{2 \mathrm{P}}$ ). more stability can be expected after PEF processing and during storage.

\subsubsection{Net change of color $(\Delta E)$}

To have a better understanding of the changes in color in milk after processing and during storage, some color functions were evaluated based on Hunter parameters. First, the net change in color was calculated for each sample, using as reference the untreated sample (same brand or model system). In Fig. 3, this behavior is shown for the four samples. For the commercial samples $\left(A_{1}, A_{2}\right)$, the net change in color was very high after day 20 ; while model system $B_{1}$ showed undefined behavior during storage, with a peak in color after 10 days of storage representing the maximum difference between the treated and untreated samples. Model system $B_{2}$ did not show any important changes during storage in $\Delta E$ probably because of the high concentration of Allura Red present in the sample.

\subsubsection{Hue angle $\left(h^{*}\right)$}

The hue angle is shown in Fig. 4, for commercial untreated samples $\left(\mathrm{A}_{1 \mathrm{C}}\right.$ and $\left.\mathrm{A}_{2 \mathrm{C}}\right) ; h^{*}$ remained constant during storage, close to $0{ }^{\circ} \mathrm{C}$, which is close to the reddish $h^{*}$ value. But in PEF processed samples the angle changed to a negative value close to the yellowish region. This change was observed at first sight as loss of color in the milk. Model systems showed similar behavior to $\Delta E$; the less concentrated sample showed a change in hue angle after 10 days of storage within the hysteresis region from day 15 to day 25 . Samples containing the most coloring agent did not change $h^{*}$ during storage and remained at a constant value, around $27^{\circ}$.

\subsubsection{Chroma $\left(C^{*}\right)$}

The saturation index or chroma $\left(C^{*}\right)$ was calculated for the samples, as shown in Fig. 5. This value, which indicates the degree of saturation, purity or intensity of color, showed a constant value for commercial samples during storage. Sample $A_{1}$ showed a higher value than sample $A_{2}$ the entire time, indicating more purity in the color of the milk. Flavored milk $A_{1}$ was a better and more expensive brand of this beverage compared to brand $A_{2}$, which could be a reason to use coloring with higher purity and other stabilizing agents, as mentioned in materials and methods. However, during storage PEF treated samples lost their Allura Red intensity, diminishing the $C^{*}$ value as observed. Model systems showed similar behavior to the previous functions, i.e., a less concentrated system, less saturation, and faster degradation with or without PEF treatment. But as Allura Red concentration was increased, the stability of the color remained despite the treatment, as observed in Fig. 5.

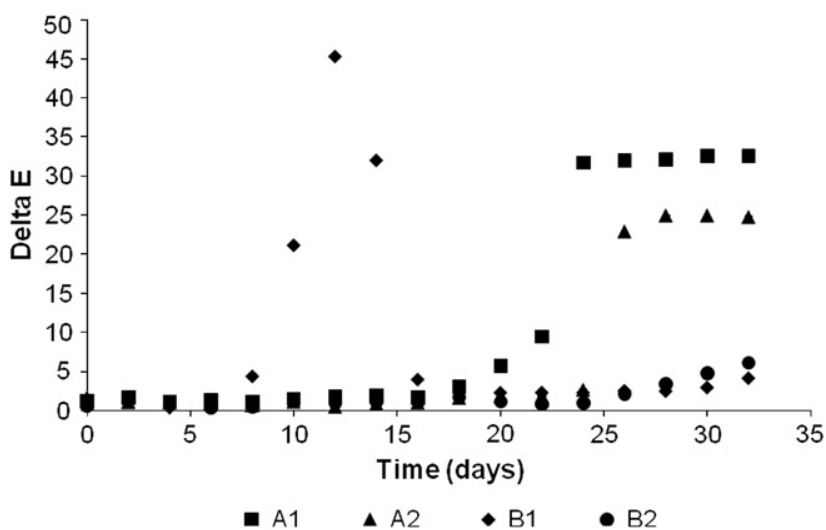

Fig. 3. Net change of color $(\Delta E)$ during storage $\left(4^{\circ} \mathrm{C}\right)$ in samples of commercial strawberry flavored milk $\left(A_{1}, A_{2}\right)$ and model systems $\left(B_{1}, B_{2}\right)$. 


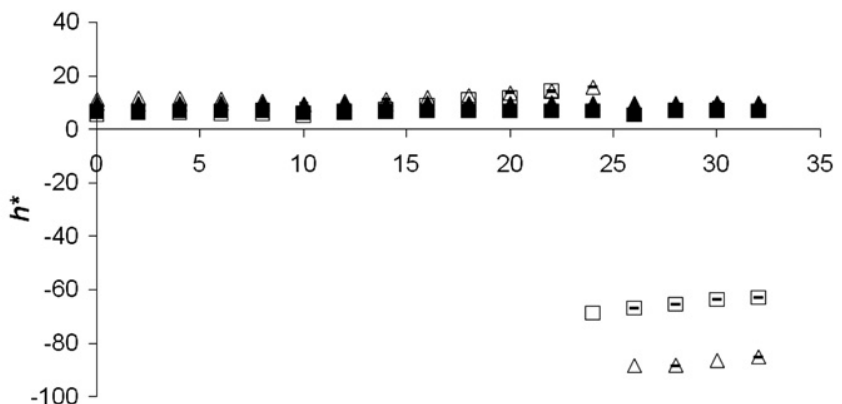

Time (days)

-A1C $\square \mathrm{A} 1 \mathrm{P} \triangle \mathrm{A} 2 \mathrm{C} \triangle \mathrm{A} 2 \mathrm{P}$

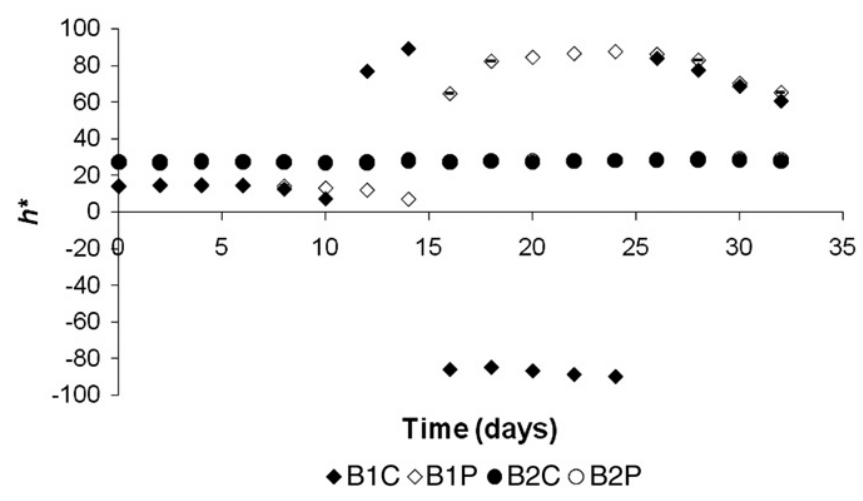

Fig. 4. Hue angle during storage $\left(4^{\circ} \mathrm{C}\right)$ for samples of strawberry flavored milk; commercial brands (control: $A_{1 C}$ and $A_{2 C}$; processed $A_{1 P}$ and $A_{2 P}$ ) and model systems (control: $\mathrm{B}_{1 \mathrm{C}}$ and $\mathrm{B}_{2 \mathrm{C}}$; processed $\mathrm{B}_{1 \mathrm{P}}$ and $\mathrm{B}_{2 \mathrm{P}}$ ).

\subsubsection{Microbiological counts}

Microbiological counts in the commercial milks before processing were too low $(<10 \mathrm{cfu} / \mathrm{ml})$ to be detected with conventional methods.
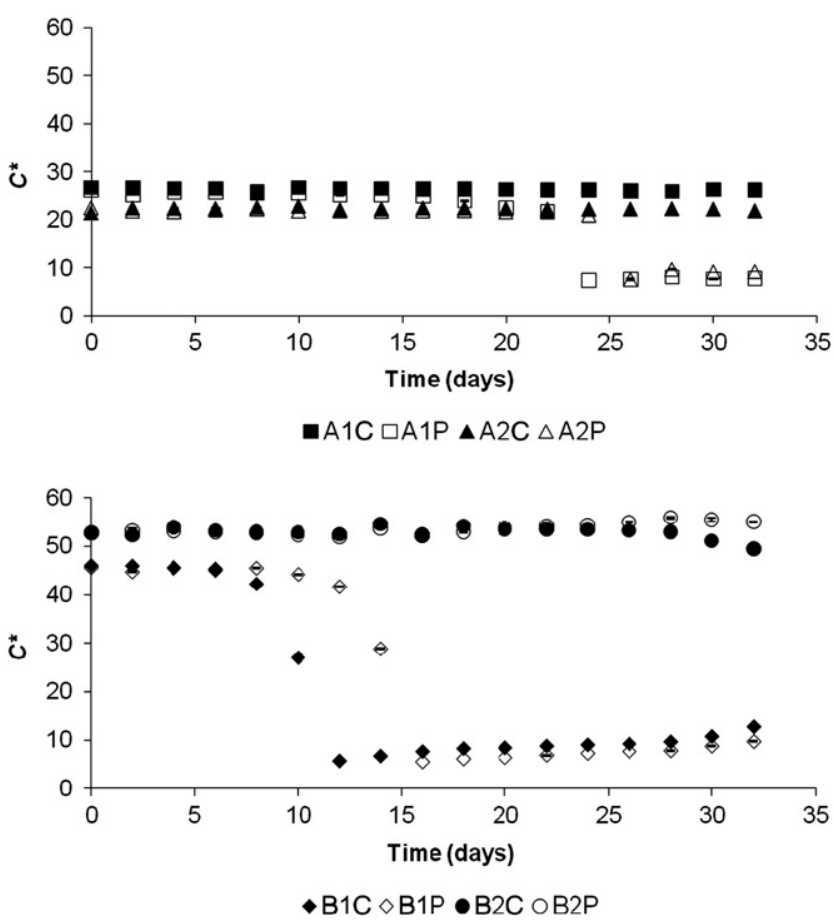

Fig. 5. Chroma or saturation index for samples during storage $\left(4^{\circ} \mathrm{C}\right)$ of strawberry flavored milk; commercial brands (control: $A_{1 C}$ and $A_{2 C}$; processed $A_{1 P}$ and $A_{2 P}$ ) and model systems (control: $\mathrm{B}_{1 \mathrm{C}}$ and $\mathrm{B}_{2} \mathrm{C}$; processed $\mathrm{B}_{1 \mathrm{P}}$ and $\mathrm{B}_{2 \mathrm{P}}$ ).

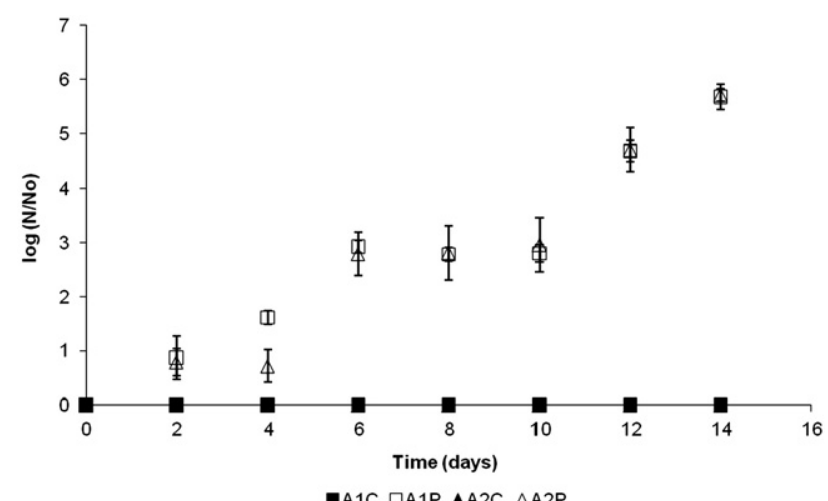

घA1C $\square \mathrm{A} 1 \mathrm{P} \triangle \mathrm{A} 2 \mathrm{C} \triangle \mathrm{A} 2 \mathrm{P}$

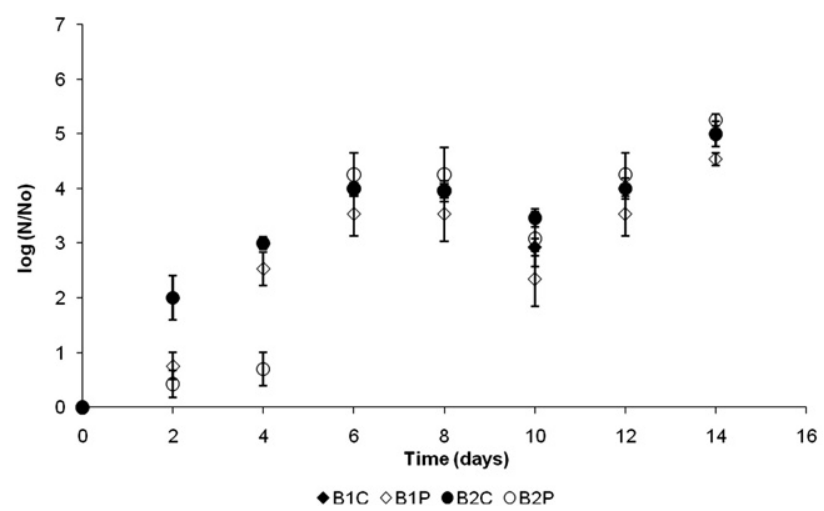

Fig. 6. Microbial growth in samples during storage $\left(4{ }^{\circ} \mathrm{C}\right)$ of strawberry flavored milk; commercial brands (control: $A_{1 C}$ and $A_{2 C}$; processed $A_{1 P}$ and $A_{2 P}$ ) and model systems (control: $\mathrm{B}_{1 \mathrm{C}}$ and $\mathrm{B}_{2 \mathrm{C}}$; processed $\mathrm{B}_{1 \mathrm{P}}$ and $\mathrm{B}_{2 \mathrm{P}}$ ).

Model systems showed less than $10 \mathrm{cfu} / \mathrm{ml}$ before processing with PEF. The growth of mesophilic bacteria after processing and during storage is shown in Fig. 6 . In the first case, the commercial samples $A_{1 C}$ and $A_{2 C}$ did not show microbial growth throughout storage, at least at a detectable level with conventional methods. Since both samples $A_{1 C}$ and $A_{2 C}$ were processed with UHT pasteurization, all mesophilic bacteria in the products were eliminated, or at least reduced to very low counts, and therefore could not be detected by pour plating. Commercial samples processed with PEF showed an increase in the bacterial population throughout storage. One reason for this increase in growth could be a possible cross contamination; although the microbial quality of the PEF system and all related materials were tested without evidence of microorganisms, there is the possibility that dormant spores of some thermally resistant microorganisms were activated with the use of PEF. After 12 days of storage, the milks $\left(A_{1 P}, A_{2 P}\right)$ showed almost a 5 log reduction in microbial growth. Model systems ( $B_{1}, B_{2}$, control, and processed) showed a similar behavior in microbial growth during storage, increasing to a $5 \mathrm{log}$ reduction after 14 days of storage. In this case, there was no difference between the commercial and model systems because the milk used for the model systems was not UHT pasteurized and contained some bacteria capable of accelerating the growth of more microorganisms. Also, PEF processing conditions were chosen based on those used for milk pasteurization without any added ingredients (just plain milk); it has been shown by others that the presence of other components (i.e. fat and protein) in the product affect the microbial inactivation by PEF and requires the strongest conditions (Sobrino-López, RaybaudiMassilia, \& Martín-Belloso, 2006). In this research the model systems showed the presence of a coloring agent, plus sucrose; even when pasteurized milk (processed at $72{ }^{\circ} \mathrm{C}, 15 \mathrm{~s}$ ) was used in the formulation, pasteurization did not inactivate all the microorganisms in milk and the growth of remaining cells could be stimulated by PEF, showing higher counts (Fig. 6). 
a)

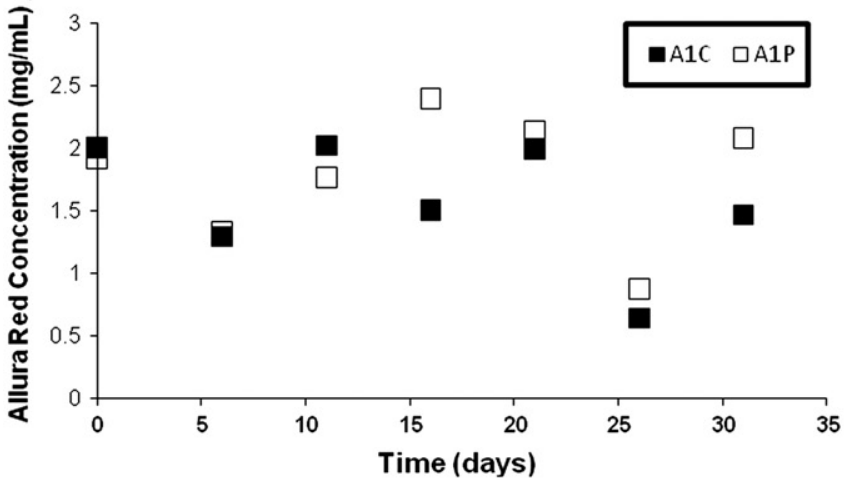

c)

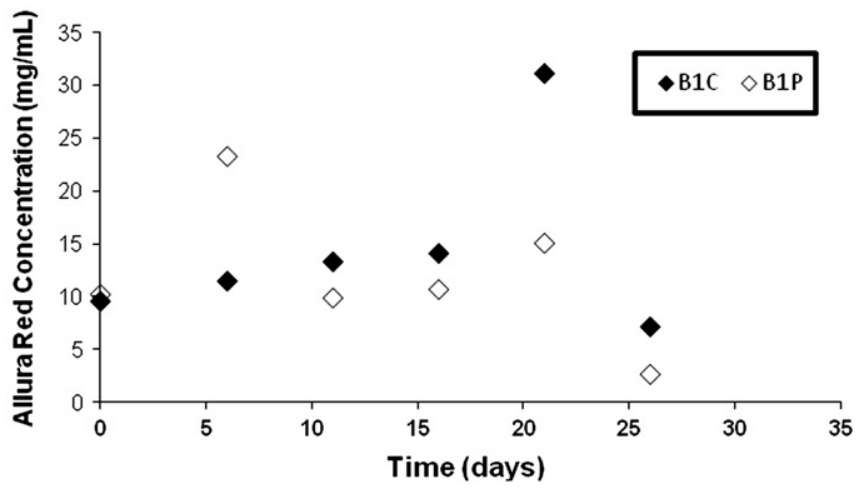

b)

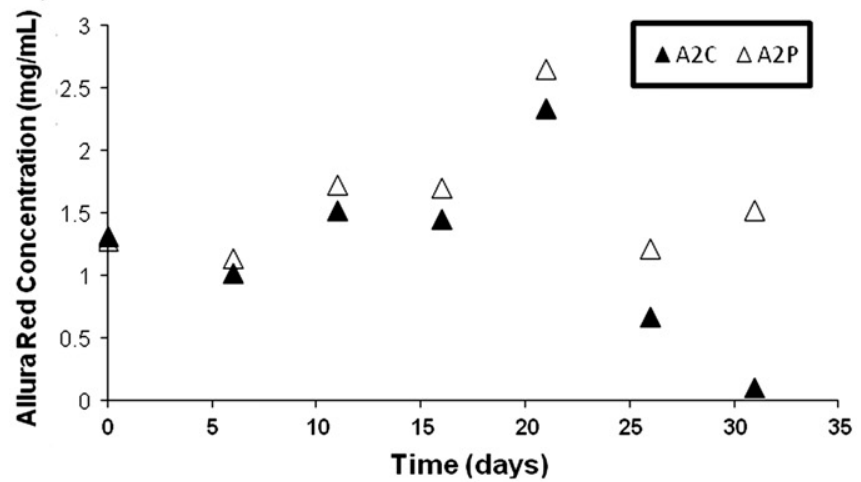

d)

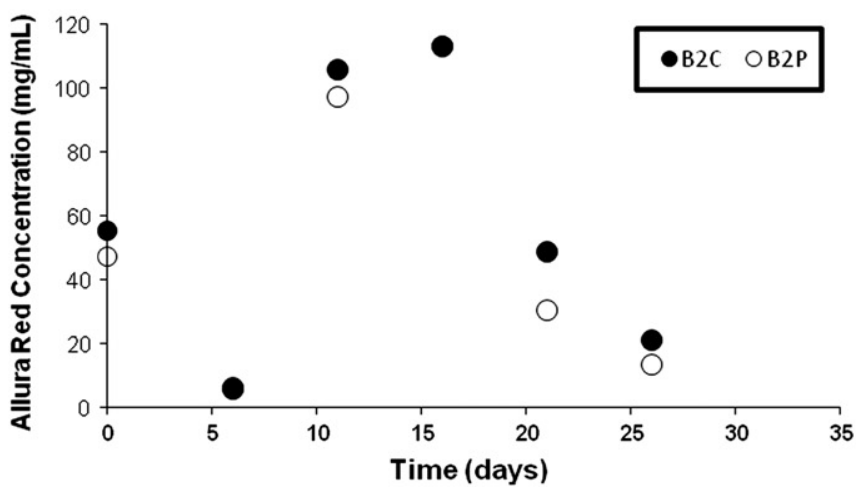

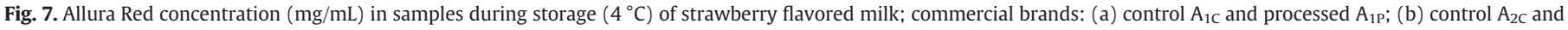
processed $A_{2 \mathrm{P}}$; and model systems: (c) control $\mathrm{B}_{1 \mathrm{C}}$ and processed $\mathrm{B}_{1 \mathrm{P}}$; (d) control: $\mathrm{B}_{2 \mathrm{C}}$ and processed $\mathrm{B}_{2 \mathrm{P}}$ ).

\subsubsection{Concentration of Allura Red}

In Fig. 7, concentration of Allura Red in all systems is shown during storage. Samples were analyzed the storage period but results only reflect up until day 31 for commercial samples and day 26 for model systems, since after these respective days of storage the HPLC values were not possible to integrate because of the presence and interference of big noisy peaks. These peaks were not present originally and their presence in later days towards the end of storage could be due to the binding of protein with the dye or other chemical reactions. The presence of other dyes such as Sunset Yellow or Tartrazine may cause interference with Allura Red because of similar azo structure (Fig. 8) (Alghamdi, 2005). Even though none of the commercial brands contain any of the above dyes, sample $A_{1}$ contains

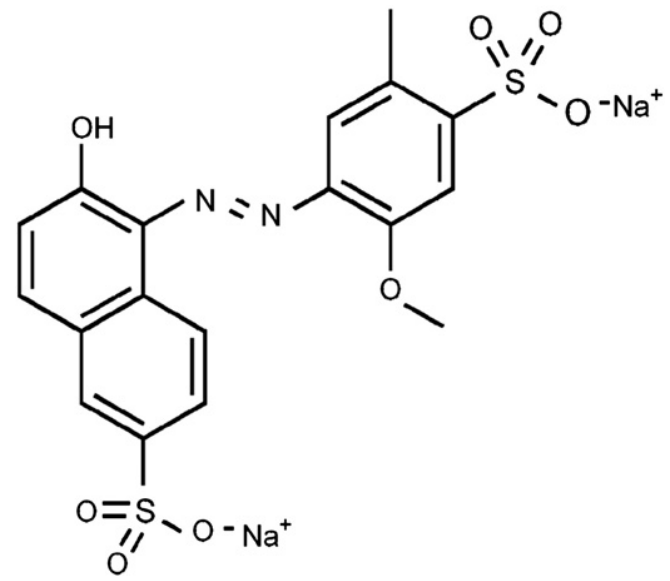

Fig. 8. Chemical structure of Allura Red (FD\&C Red No. 40); chemical name, disodium (5Z) -5-[(2-methoxy-5-methyl-4-sulfonatophenyl) hydrazinylidene]-6-oxonaphthalene2-sulfonate. the dye Blue 1, which is a charged molecule (Fig. 9); and sample $A_{2}$ contains some artificial flavors, which could be interacting with Allura Red. The first part of Fig. 7 shows the behavior of commercial brand $A_{1}$; both samples, untreated $\left(A_{1 C}\right)$ and PEF treated $\left(A_{1 P}\right)$, showed a constant concentration during storage; the PEF sample even showed a slight increase in concentration. For the commercial sample $A_{2}$, concentration of the coloring agent showed a maximum peak of $2.5 \mathrm{mg} / \mathrm{mL}$ after 20 days of storage; opposite behavior was observed for the untreated sample $\left(A_{2 C}\right)$ and the PEF sample $\left(A_{2 P}\right)$ after day 26 , with an important decrease in the $A_{2}$ sample at end of storage period.

The model systems showed different behaviors. Model system $B_{1}$ had an almost constant concentration of coloring agent during storage with a final drop of coloring agent. Meanwhile, model system $B_{2}$ presented the same concentration in the untreated $\left(B_{2 C}\right)$ and treated $\left(\mathrm{B}_{2 \mathrm{P}}\right)$ samples, although concentration did not follow a constant trend. Reports on stability data for FD\&C Red No. 40 shows that this dye has very good stability regardless of $\mathrm{pH}$ (from 3 to 8 ); it is stable with light, heat (up to $105^{\circ} \mathrm{C}$ ), acid ( $10 \%$ acetic acid), and presence of<smiles>CCN(Cc1cccc(S(=O)(=O)O)c1)c1ccc(C(=C2C=CC(=[N+](CC)Cc3cccc(S(=O)(=O)O)c3)C=C2)c2ccccc2[S+](=O)(=O)O)cc1</smiles>

Fig. 9. Chemical structure of Brilliant Blue (FD\&C Blue No. 1); chemical name, disodium 2-[[4-[ethyl-[(3-sulfonatophenyl) methyl] amino] phenyl]-[4-[ethyl-[(3- sulfonatophenyl) methyl] azaniumylidene] cyclohexa-2, 5-dien-1-ylidene] methyl] benzenesulfonate. 
$\mathrm{SO}_{2}$; the colorant also shows fair stability in the presence of base (Thorngate, 2002).

So, the changes observed in the coloring agent in these samples are not a result of changes in $\mathrm{pH}$ or increase of temperature (in all experiments temperature was kept below $55^{\circ} \mathrm{C}$ ); one theory that could describe these changes is the possibility of binding between the colorant agent and some other charged molecules in milk because of the presence of strong electric fields attracting particles and forming new matrices; this could thus change the electron configuration of the molecules and scatter or absorb the light in different ways and produce different colors to the human eye. Even though color and concentration of Allura Red are two different aspects, as studied in this research, the intensity of the color is directly correlated with the concentration of the coloring agent. Some samples lost intensity of color and there were some variations in Allura Red concentration during storage (Fig. 7). These facts could be related to chemical reactions taking place during storage as well as the microbial growth observed in samples processed with PEF. The affinity of Allura Red with proteins has been shown in work by Abdullah et al. (2008) in which the dye was attached to casein fractions and the effect enhanced by heat as previously mentioned. Because of the thermal effect in protein denaturation, Allura Red showed improved and constant binding with the casein. Even though PEF is a nonthermal technology, it is clear that during pulsing inside the treatment chamber there is an increase of temperature lasting a few seconds; as a result, milk proteins like casein could be attaching some dye molecules and forming stronger structures that could be broken instantaneously because of the intensity of the electric field applied at the same time inside the chamber. Sample $A_{1}$, containing molecule of Blue 1 (Fig. 9), is a good example of the possible interaction between dyes after PEF processing. Blue 1 has some charged groups that could be reacting and experiencing a rearrangement in electron configuration after interaction with pulsed electric fields. The interaction with other components in the food such as sugar, starch and other dyes could also interfere with the detection and quantification of Allura Red (López-de-Alba, Wróbel-Kaczmarczyk, Wróbel, López-Martínez, \& Amador Hernández, 1996). However, further research on flavored milks must be conducted to obtain a better explanation of what is happening with the electrons of the molecules and the new complexes and chemical reactions taking place during and after PEF processing. The possibility of formation of new compounds is also high, which should be carefully studied to eliminate any possibility of toxicological reactions. Also, other processing conditions should be studied in more complex systems different from plain milk that could be of interest because of the presence of other macromolecules.

\section{Conclusions}

Pulsed electric fields technology is a nonthermal method that could offer important energy and cost savings to the dairy industry in the pasteurization of milk. However, because of the interaction of electricity between charged molecules in milk with coloring agents and other additives during PEF treatment, new matrices were formed within the product in the studied PEF processed milk samples, resulting in a lack of color after some days of storage. But the presence of other ingredients and dyes helped retain this color after PEF processing in the commercial samples. The concentration level of
Allura Red also showed better stability of color in samples at higher concentrations regardless of treatment.

\section{Acknowledgments}

The authors acknowledge the economic support of this project by US Army Natick.

\section{References}

Abdullah, S. U., Badaruddin, M., Sayeed, S. A., Ali, R., \& Riaz, M. N. (2008). Binding ability of Allura Red with food proteins and its impact on protein digestibility. Food Chemistry, 110, 605-610.

Al-Degs, Y. S. (2009). Determination of three dyes in commercial soft drinks using HLA/ GO and liquid chromatography. Food Chemistry, 117, 485-490.

Alghamdi, A. H. (2005). Determination of Allura Red in some food samples by adsorptive stripping voltammetry. Journal of AOAC International, 88(5), $1387-1393$.

Anonymous (1984). Allura Red-Developmental and psychotoxic effects? Food and Chemical Toxicology, 22(11), 913.

Bendicho, S., Barbosa-Cánovas, G. V., \& Martín-Belloso, O. (2002). Milk processing by high intensity pulsed electric fields. Trends in Food Science and Technology, 13(6), 195-204.

CFR. (2001). Code of Federal Regulations, FD\&C Red No. 40. Title 21, Volume 1. Part 74.340 .

Chen, Q., Mou, S., Hou, X., Riviello, J. M., \& Ni, Z. (1998). Determination of eight synthetic food colorants in drinks by high-performance ion chromatography. Journal of Chromatography. A, 827, 73-81.

Craven, H. M., Swiergon, P., Ng, S., Midgely, J., Versteeg, C., Coventry, M. J., \& Wan, J. (2008). Evaluation of pulsed electric fields and minimal heat treatments for inactivation of pseudomonads and enhancement of milk shelf-life. Innovative Food Science \& Emerging Technologies, 9(2), 211-216.

Gifford, S. R., \& Clydesdale, F. M. (1986). The psychophysical relationship between color and sodium chloride concentrations in model systems. Journal of Food Protection, 49(12), 977-982.

Kirschbaum, J., Krause, C., Pfalzgraf, S., \& Brückner, H. (2003). Development and evaluation of an HPLC-DAD method for determination of synthetic food colorants. Chromatographia, 57(1), S115-S119.

Lewis, R. J. (1989). Food Additives. New York: Van Nostrand Reinhold Company.

Lonnerdal, B., Woodhouse, L. R., \& Glazier, C. (1987). Compartmentalization and quantitation of protein in human milk. The Journal of Nutrition, 117(8), 1385-1395.

López-de-Alba, P. L., Wróbel-Kaczmarczyk, K., Wróbel, K., López-Martínez, L., \& Amador Hernández, J. (1996). Spectrophotometric determination of Allura Red (R40) in soft drink powders using the universal calibration matrix for partial least squares multivariate method. Analytica Chimica Acta, 330, 19-29.

Miller, G.D., Jarvis, J.K., \& McBean, L.D. (2007). Handbook of Foods and Nutrition. $3^{\text {rd }}$ Boca Raton, FL: CRC Press.

NSRDEC (2007). US Army Natick Soldier Center. Operational Rations of the Department of the Defense, 7th Ed. Natick, MA: Department of Defense.

Odriozola-Serrano, I., Bendicho-Porta, S., \& Martín-Belloso, O. (2006). Comparative study on shelf-life of whole milk processed by high intensity pulsed electric fields or heat treatment. Journal of Dairy Science, 89(3), 905-911.

Qin, B. L., Pothakamury, U. R., Vega, H., Martín, O., Barbosa-Cánovas, G. V., \& Swanson, B. G. (1995). Food pasteurization using high-intensity pulsed electric fields. Food Technology, 49, 55-60.

Sepúlveda, D. R., Góngora-Nieto, M. M., Guerrero, J. A., \& Barbosa-Cánovas, G. V. (2005). Production of extended-shelf life milk by processing pasteurized milk with pulsed electric fields. Journal of Food Engineering, 67, 81-86.

Sobrino-López, A., \& Martín-Belloso, O. (2008). Enhancing the lethal effect of highintensity pulsed electric field in milk by antimicrobial compounds as combined hurdles. Journal of Dairy Science, 91, 1759-1768.

Sobrino-López, A., Raybaudi-Massilia, R., \& Martín-Belloso, O. (2006). High-intensity pulsed electric field variables affecting Staphyloccocus aureus inoculated in milk. Journal of Dairy Science, 89, 3739-3748.

Tennant, D. R. (2008). Screening potential intakes of colour additives used in nonalcoholic beverages. Food and Chemical Toxicology, 46, 1985-1993.

Thorngate, J. H., III (2002). Synthetic Food Colorants. In A. L. Branen, P. M. Davidson, S. Salminen, \& J. H. ThorngateIII (Eds.), Food Additives (pp. 477-500). 2nd Ed. New York: Marcel Dekker, Inc.

WO/2004/100671. Flavored milk manufacturing processes and compositions. World Intellectual Property Organization. 